\title{
Triadism and processuality
}

\author{
Juuso-Ville Gustafsson \\ Department of Philosophy, University of Turku \\ 20014 Turku, Finland \\ e-mail: juuso-ville.e.gustafsson@utu.fi
}

\begin{abstract}
This paper examines the connections between triadism and processuality in Peirce's semiotics by comparing two reducibility theses. Peirce's thesis regarding the irreducibility of triads and its corollary in semiotics, the irreducibility of signs, is compared with the process metaphysical thesis regarding the irreducibility of processes. The comparison indicates that (1) there is a connection between the irreducibility of signs and the irreducibility of processes; (2) that the triadic condition of the sign entails process metaphysical commitments; and this in turn (3) urges us to consider the ontology of the sign from a process metaphysical perspective.
\end{abstract}

Keywords: triadism, process metaphysics, processualism, irreducibility of triads, irreducibility of processes, Peircean semiotics, conceptual processualism

\section{Introduction}

In this short paper I examine the connections between triadism and processuality in Peircean semiotics by comparing two reducibility theses. I compare Charles Peirce's thesis regarding the irreducibility of triads and its corollary in semiotics, the irreducibility of signs, with the process metaphysical thesis regarding the irreducibility of processes. The comparison indicates that there is a connection between the irreducibility of signs and the irreducibility of processes, that the triadic condition of the sign entails process metaphysical commitments, and that this in turn urges us to consider the ontology of the sign from a process metaphysical perspective.

\section{Triadism and the irreducibility of triads}

Peirce's philosophy is marked by a tendency to divide everything into threes. This tendency has been given various names in the literature such as "triadism" (see Burch 
2014, Section 9) ${ }^{1}$ and "triadomania" (see Spinks 1991). Even Peirce himself was aware of his habit and referred to it as "triadomany" - insisting that he only adheres to it for “truth's sake” (CP 1.568 in Bergman, Paavola 2015). ${ }^{2}$ According to Robert Burch, Peirce scholars still have but a hunch as to what the actual rationale for Peirce's triadism is. Burch speculates that Peirce's triadism may have originated from his logic-derived doctrine of categories, the influence of the philosophies of Hegel and Kant, or from the "triune commitments of orthodox christianity" (Burch 2014, Section 9). Whatever the actual reason might be, it is eminently clear that triadism plays an important role in Peirce's philosophy. Regardless of these different perspectives on triadism, in contemporary works dealing with Peirce's philosophy and semiotics the categoryapproach is favoured and triadism is usually linked with the doctrine of categories and its logico-mathematical origins. It is not, however, triadism as a tendency that is interesting. Instead, it is the idea related to it, concerning the fundamental and irreducible nature of triads that is most intriguing.

Peirce discusses the fundamental and irreducible nature of triads in his "A guess at the riddle" in which he defends his three categories. While discussing the nature of thirds Peirce writes:

But it will be asked, why stop at three? Why not go on to find a new conception, in Four, Five, and so on indefinitely? The reason is that while it is impossible to form a genuine three by any modification of the pair, without introducing something of a different nature from the unit and the pair, four, five and every higher number can be formed by mere complications of threes. [...] The fact that $\mathrm{A}$ presents $\mathrm{B}$ with a gift $\mathrm{C}$, is a triple relation, and as such cannot possibly be resolved into any combination of dual relations. Indeed, the very idea of a combination involves that of thirdness, for a combination is something which is what it is owing to the parts which it brings into mutual relationship. (Peirce 1991: 192)

Peirce has also expressed a similar point elsewhere as follows:

[E]very polyad higher than a triad can be analyzed into triads, though not every triad can be analyzed into dyads. (MS 439, 16, quoted in Roberts 1973: 115)

These passages bring out the fundamentality of triads and express what some have called "the irreducibility of triads" (Roberts 1973: 115), "the irreducibility claim"

\footnotetext{
$1 \quad$ Burch, Robert 2014. Charles Sanders Peirce. In: Zalta, Edward N. (ed.), The Stanford Encyclopedia of Philosophy (Winter 2014 Edition) retrieved from http://plato.stanford.edu/ archives/win2014/entries/peirce/.

2 Bergman, Mats; Paavola, Sami 2015. Triadomany. In: Bergman, Mats; Paavola, Sami (eds.), The Commens Dictionary: Peirce's Terms in His Own Words. (New ed.) Retrieved from http:// www.commens.org/dictionary/term/triadomany, 15.10.2015.
} 
(Brunning 1997: 252), or "Peirce's reduction thesis" (Burch 2014, Section 14; Burch 1997). The irreducibility of triads is not a trivial idea, since it has been proved as correct (see Burch 1997) and because it was used by Peirce to justify his category of thirdness (Brunning 1997: 252). The thesis is also relevant for semeiotics due to the interrelated or inseparable nature of Peirce's logic and semeiotics (see Bellucci 2014). The central idea in Peirce's thesis is that triads (in their genuine, non-degenerate form) are something fundamental, since they can neither be reduced to dyadic relations nor built from monadic or dyadic relations (cf. Burch 2014, Section 14); moreover, all relations of a higher arity than three can be constructed from triads. This idea, specifically the part regarding the irreducibility of triads, is interesting when examined in the context of Peirce's semiotics due to the implications it has on the nature of the sign and its ontology.

Indeed, the logico-mathematical idea regarding the irreducibility of triads is connected with the irreducibility of signs in semeiotics through Peirce's theory of categories, specifically through the category of thirdness. As Peirce writes in his letters to Lady Welby that "[i]n its genuine form, Thirdness is the triadic relation existing between a sign, its object, and the interpreting thought, itself a sign, considered as constituting the mode of being of a sign" (CP 8.332 as quoted in Pietarinen 2006: 18). Thus the triadic sign relation, in its non-degenerate form, exemplifies genuine thirdness and as such should also be considered as irreducible. Thus what holds for genuine triads and triadic relations, holds for genuine or non-degenerate signs. This is not, however, anything new. Remarking on the connection between Peirce's semeiotics and phenomenology, Mats Bergman writes that:

The simplest way to describe what distinguishes semeiotic from other major variants of semiotics is to say that it is based on the premise that the sign relation is irreducibly triadic. [...] The claim that semeiotic depends on the theory of categories is almost as self-evident, for Peirce singles out the conceptions of sign, representation, and medium as prime exemplars of thirdness (see, e.g. CP 1:337, c. $1875 ; 1.532,1903 ; 1.537,1903)$. (Bergman 2009: 67)

He also points out that:

The sign relation is decidedly akin to giving; as noted, Peirce portrays the basic semiotic relation as an irreducible triad that can be articulated schematically as '- represents - to - ' or as ' - mediates between - and -'. This suggests that the conception of the generic sign relation may be obtained by moving from mathematics to grammar via phenomenology, where the role of the latter is to detect the appearance of certain triadic phenomena - signs, representations, or mediums - that conform to the mathematical categories. (Bergman 2009: 74) 
The irreducible nature of the sign has also been seen as constituting one of the four conditions of signhood. According to Liszka, we can distinguish four formal conditions of signs, the fourth of which he calls the "triadic condition" of the sign (Lizska 1996: 19). He formulates this condition as follows:

The relation among sign (in regard to its ground), object and interpretant must be triadic, that is, thought of as an irreducible interrelation through which each component gets its sense (CP 5.484), so that the sign's power to represent is mediated by its grounding and interpretation and, similarly, for each of the other components. [...] Thus grounding, representation, and interpretation are triadically interdependent. So, in its most general and fullest terms, a sign must represent something in some respect to some interpreter in order to count as a sign (CP. 2.228). (Liszka 1996: 19)

As this triadic condition of the sign requires, a sign in its non-degenerate form must be understood as a triadic unity (a genuine triadic relation) that cannot be reduced to dyadic relations between its elements. Peirce also discussed the irreducible nature of triadic signs in connection with the action of signs that he called semiosis. Peirce defined semiosis as "an action, or influence, which is, or involves, a cooperation of three subjects, such as a sign, its object, and its interpretant, this tri-relative influence not being in any way resolvable into actions between pairs" (EP 2.411). The sign, apart from being a genuine and irreducible triadic relation, must thus also be seen as a functional unity, that is, as an action or a process. And according to Liszka, it is exactly the triadic condition of the sign that explains semiosis, the functional character of the sign (Liszka 1996: 32).

It is this connection between triadism and the processual nature of the sign that is most curious. Triadism, the fundamentality of triads, and the idea regarding their irreducibility, leads us to consider the non-degenerate sign as a functional triadic unity. If the elements of the sign are irreducibly interrelated, as the triadic condition of the sign requires, and a sign must be seen as a kind of action, then the best way to characterize a sign would be to call it a triadic process. Moreover, if such triadic sign processes are irreducible, then we somehow have to take them as they are. This, however, leads to interesting process metaphysical commitments regarding the ontology of the sign. In order to illustrate this connection further, let us examine a thesis similar to the irreducibility of triads. 


\section{The irreducibility of processes}

The "process reducibility thesis" is a metaphysical thesis regarding the nature of processes. This thesis claims that all processes are subordinate to substantial things and that the activity of these things is what constitutes a process (Rescher 1996: 43-44). The thesis further claims that " $\mathrm{t}]$ here just are no processes apart from those that constitute the activity of identifiable agents. All process is reducible to the doings of (nonprocessual) things" (Rescher 1996: 44). The thesis has two parts: the giving of primacy and priority to things. Giving priority to things means that "[...] the only sort of processes there are are those involved in the doings and comportments of things" (Rescher 1996: 2), that is, all processes are made up of the action of things. And giving primacy to things means that things are all there is (Rescher 1996: 2). The process reducibility thesis thus claims that processes consist primarily of things and the actions of things (Rescher 1996: 2, 42-43). From this perspective reality is best understood in terms of things, and all processes must, in principles, be reducible to the action of things. This position is, however, incompatible with the Peircean conception of the sign as a genuine and irreducible triadic relation, since adopting such a perspective would require that non-degenerate signs can somehow be reducible.

The "process reducibility thesis" is a starting point for process metaphysics as it is this thesis that it opposes (Rescher 1996: 43). According Nicholas Rescher (1996: 44), process metaphysics instead claims that "[...] things are constituted out of the flow of process, and substantiality is subordinate to activity. Things simply are what they do". Process metaphysics can be formulated in terms of an opposing thesis that could called the irreducibility of processes thesis. This thesis would also have two parts: the giving of primacy and priority to processes. Giving primacy to processes would mean that "[s]ubstance is subordinate to process: things are simply constellations of processes" (Rescher 1996: 2). And giving priority to a processes would mean that "[ $\mathrm{t}$ ]hings are always subordinate to processes because processes inwardly engender, determine, and characterize the things there are" (Rescher 1996: 2). It is therefore clear that process metaphysics, or at least those committed to process metaphysics and the irreducibility of processes thesis, holds that true processes cannot be seen as or reducible to the activity of things. Process metaphysics thus allows the existence of irreducible processes and in this respect it also provides a better ontological framework for the sign as an irreducible triadic process than orthodox substance ontology.

Rescher also makes a distinction between owned and unowned processes. He defines the two types of processes in the following way:

Owned processes are those that represent the activity of agents [...]. Such processes are ownership attributable with respect to "substantial items". Unowned processes, by contrast, are free floating, as it were, and do not represent the activity of actual 
(i.e., more than nominal) agents [...]. From the process philosopher's point of view, the existence of unowned processes is particularly important because it shows that the realm of process as a whole is something additional to and separable from the real of substantial things. (Rescher 1996: 42)

As pointed out before, the sign, in its non-degenerate form, is a true triadic relation and thus it is something irreducible. Following the above-cited distinction, signs could further be classified as unowned processes, as "something additional to and separable from the real of substantial things" (Rescher 1996: 42). And this in turn would make the sign a true process.

As the considerations above indicate, there is a curious connection between the irreducibility of signs and the irreducibility of processes. The triadic condition of the sign entails process metaphysical commitments for semiotics regarding the ontology of the sign, because it requires that signs are genuinely triadic and thus irreducible. The most important of these commitments is, however, the idea that both the sign and its ontology should be seen in processual terms. This in turn brings triadism and processuality in connection with each other. Let us now move on to discuss the relationship between the two irreducibility theses as introduced above.

\section{Irreducibility theses in comparison}

The irreducibility of triads thesis and its equivalent (or corollary) in the theory of signs, the triadic condition of the sign, is similar to the irreducibility of processes thesis in process metaphysics. Both claim that their object of interest (signs as triadic relations and processes as such) cannot be reduced to the action of their parts or seen as the action of things, but instead should be taken as they are.

Triadism holds that triads are fundamental, since they cannot be constructed out of or reduced to monads or dyads, and that more complex relations can be reduced to or constructed out of triads. In the context of the theory of signs this translates into a processual conception of the sign as an irreducible functioning triadic unity. Processualism similarly holds that processes cannot be reduced to the doings of things and this is why processes should be given primacy or priority in ontology. Processualism, however, comes in two different variants. If triadism entails processuality, then the question is what kind of processualism does it entail?

Rescher makes a distinction between ontological and conceptual process metaphysics. He defines the two in the following way:

The conceptual aspect is based on the idea that process and its ramifications affords the most appropriate and effective conceptual instruments for understanding the 
world we live in. And the ontological aspect inheres in the idea that this conceptual state of affairs obtain because process is the most pervasive, characteristic, and crucial feature of reality. This duality of doctrinal perspective leads to there being two distinct (albeit compatible) versions of process philosophy. In its stronger version, process philosophy is an ontological reductionism that sees all physical things as reducible to physical processes. In its weaker version, process philosophy is a conceptual reductionism that sees the explanation of the idea of a "thing" as necessarily involving a recourse to processual ideas. (Rescher 1996, 28)

Following Rescher, we might say that triadism entails a conceptual processualism that requires recourse to processual ideas in order to make sense of the sign and its irreducibility. The triadism-processuality connection also raises other questions. If triadism somehow causes processuality, must all genuine processes be triadic? For it might be true that all triads are processes, but all processes are not triads. And if triadism is linked with processuality, must all semiotic processes be triads? Whatever, the answer to these open questions might be, it seems that there is a similarity between the irreducibility of triads, its semiotic corollary, and the irreducibility of processes. Moreover, it is this similarity that seems to have interesting implications for the sign and its ontology. At the very least, it urges us to reconsider the ontology of the sign from a process metaphysical perspective. ${ }^{3}$

\section{References}

Bellucci, Francesco 2014. 'Logic, considered as semeiotic': On Peirce's philosophy of logic. Transactions of the Charles S. Peirce Society: A Quarterly Journal in American Philosophy 50(4): 523-547.

Bergman, Mats 2009. Peirce's Philosophy of Communication: The Rhetorical Underpinnings of the Theory of Signs. London: Continuum.

Brunning, Jacqueline 1997. Genuine triads and teridentity. In: Houser, Nathan; Roberts, Don D., Van Evra, James (eds.), Studies in the Logic of Charles Sanders Peirce. Bloomington: Indiana University Press, 252-263.

Burch, Robert 1997. Peirce's reduction thesis. In: Houser, Nathan; Roberts, Don D., Van Evra, James (eds.), Studies in the Logic of Charles Sanders Peirce. Bloomington: Indiana University Press, 234-251.

CP = Peirce, Charles S. 1931-1958. Collected Papers of Charles Sanders Peirce. Cambridge: Harvard University Press. [Hartshorne, Charles; Weiss, Paul; Burks, Arthur W. (eds.). In-text references are to $\mathrm{CP}$, followed by volume and paragraph numbers.]

Liszka, James 1996. A General Introduction to the Semeiotic of Charles Sanders Peirce. Bloomington, Indianapolis: Indiana University Press.

3 Acknowledgements: I thank Ahti-Veikko Pietarinen for his comments. I also thank the anonymous referee for helpful comments and corrections. 
Peirce, Charles Sanders 1991. A guess at the riddle. In: Hoopes, James (ed.), Peirce on Signs: Writings on Semiotic by Charles Sanders Peirce. Chapel Hill, London: University of North Carolina Press, 186-202.

- 1998. The Essential Peirce. Vol. 2. Peirce edition Project. Bloomington: Indiana University Press. [In-text references are to EP.]

Pietarinen, Ahti-Veikko 2006. Signs of Logic: Peircean Themes on the Philosophy of Language, Games, and Communication. (Synthese Library 329.) Dordrecht: Springer.

Rescher, Nicholas 1996. Process Metaphysics: An Introduction to Process Philosophy. Albany: State University of New York Press.

Roberts, Don D. 1973. The Existential Graphs of Charles S. Peirce. The Hague: Mouton Publishers.

Spinks, Cary W. 1991. Peirce and Triadomania: A Walk in the Semiotic Wilderness. Berlin, New York: Mouton de Gruyter.

\section{Триадичность и процессуальность}

В статье исследуются связи между триадичностью и процессуальностью в семиотике Пирса, сравниваются два тезиса о редуцируемости (reducibility). Тезис Пирса о нередуцируемости триад и его расширение в семиотике - нередуцируемость знаков сравнивается с метафизическим тезисом о нередуцируемости процессов. Сравнение показывает: (1) что есть связь между нередуцируемостью знаков и нередуцируемостью процессов, (2) что триадическая сущность знака влечет за собой процесс метафизических обязательств, и это в свою очередь (3) побуждает нас рассматривать онтологию знака в процессе метафизической перспективы.

\section{Triaadilisus ja protsessuaalsus}

Artiklis vaadeldakse triaadilisuse ja protsessuaalsuse seoseid Peirce'i semiootikas, võrreldes kahte taandatavuse kohta käivat teesi. Peirce'i teesi kolmikute taandamatuse kohta ning selle tuletust semiootikas, et märgid on redutseerimatud, võrreldakse protsessimetafüüsilise teesiga protsesside taandamatuse kohta. See võrdlus osutab, et (1) on olemas seos märkide taandamatuse ja protsesside taandamatuse vahel, (2) et märgi kolmetise oluga kaasnevad protsessimetafüüsilised järelmid ja see omakorda (3) õhutab meid vaatlema märgi ontoloogiat protsessimetafüüsilisest perspektiivist. 